\title{
SEED TECHNOLOGY RESEARCH IN BRAZIL: EVOLUTION AND PERSPECTIVE
}

\author{
J.B. FRANÇA-NETO'; ${ }^{1}$ M.J. OLIVEIRA ${ }^{2}$

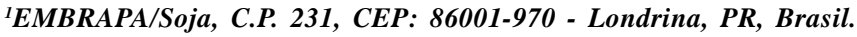 \\ ${ }^{2}$ EMBRAPA/SAIN, C.P. 040315, CEP: 70770-901 - Brasília, DF, Brasil.
}

\begin{abstract}
A brief review about the historical evolution of seed technology research in Brazil is presented, pointing out the most important facts that contributed to the development of our seed production complex and research system. The role of PLANASEM and AGIPLAN and their cooperative projects with UFPEL, ESALQ and Mississippi State University is mentioned. Major seed related publications and events, such as seminars and congresses, which contributed to the development of seed research are included and analyzed. A survey of the most important lines of seed technology research conducted in Brazil is presented. Additionally, the Brazilian universities and research institutions that significantly contributed to seed research in the past 30 years are identified. Possible tendencies and perspectives for seed research in the next five years are conjectured.
\end{abstract}

Key Words: seed programs, seed publications, seed events, seed teaching

\section{A PESQUISA EM TECNOLOGIA DE SEMENTES NO BRASIL: EVOLUÇÃO E PERSPECTIVAS}

RESUMO: Apresenta-se uma síntese da evolução histórica da pesquisa em tecnologia de sementes no Brasil, destacando os fatos mais importantes que contribuíram para o desenvolvimento dos sistemas de produção e de pesquisa. O papel do PLANASEM e do AGIPLAN e seus projetos cooperativos com a UFPEL, a ESALQ e com a Universidade Estadual do Mississippi são abordados. As principais publicações da área de sementes e os mais importantes eventos, como seminários e congressos, que efetivamente contribuíram para o desenvolvimento da pesquisa em sementes, são destacados e analisados. Um levantamento das principais linhas de pesquisa em tecnologia de sementes realizadas no Brasil é apresentado. Além disso, são identificadas as universidades e demais instituições de pesquisa que mais contribuíram, nos últimos 30 anos, para o progresso da pesquisa em sementes no Brasil. Tendências e perspectivas para a pesquisa brasileira em sementes para os próximos cinco anos são conjeturadas. Descritores: programa em sementes, publicações sobre sementes, eventos sobre sementes, ensino em sementes

\section{INTRODUCTION}

Most of the research in seed technology conducted in the United States of America and in the majority of the European countries started in conjunction with the early developments and organization of the seed industry, which occurred in the beginning of the present century. Primordial studies in seed technology research in Brazil started approximately in the same period, but the phase with the greatest developments occurred after 1970, as will be described in the following section.

The evolution of seed technology research in Brazil may be measured by several means and it depends on the period taken into consideration. In this report, the evolution will focus mainly on the last 20 years, although it will also be superficially described from its early stages.

Seed technology scientific production in Brazil was organized for the first time by Wetzel (1972), who published the "Lista Bibliográfica de Sementes" (Bibliographic List of Seeds). This publication contains all available references dating from 1917. Later on, this list was expanded to five volumes of the "Bibliografia Brasileira de Sementes" (Brazilian Seed Bibliography), published by EMBRAPA (1980-83), which includes 2842 references from the Colonial period to 1982. In 1981, Menezes et al. (1981) did a quantitative analysis of the first three volumes of the Brazilian Seed Bibliography, surveying the major seed research lines that were conducted in the period. 
Wetzel et al. (1981) did a comprehensive research on the Brazilian bibliography on seed pathology, in the period from 1926 to 1980 , including 428 references, listed by author and subject.

Popinigis (1983) presented a summary of the scientific production published in the first five volumes of the Brazilian Seed Journal (Revista Brasileira de Sementes). A more detailed study on this journal was performed by Oliveira (1994), who checked over all issues edited from 1979 to 1993. She pointed out the most productive authors in the period and the most frequently studied seed crops.

EMBRAPA-CNPH (National Center for Horticultural Research) listed 1058 papers about horticultural seeds, published from 1940 to 1995 , in the Brazilian bibliography of horticultural crops (EMBRAPA, 1995).

Recently, Oliveira (1997) performed a complete study on the evolution of seed research in Brazil. In her Doctoral dissertation, she analyzed in detail several indicators of scientific productivity, events, national plans and programs, postgraduate courses and specific institutions involved in seed investigation.

Several sources may be used for additional studies on evolution of seed research in Brazil: the Annals of the four Brazilian Seed Seminars and of the ten Brazilian Seed Congresses; the Brazilian Seed Journal (Revista Brasileira de Sementes) and the "Informativo ABRATES" (the newsletter from ABRATES-Brazilian Association of Seed Technology), are all excellent publications which contain most of the seed research conducted in the last 31 years.

\section{HISTORICAL EVOLUTION OF SEED RESEARCH IN BRAZIL}

A brief historical evolution of seed research in Brazil will be explained in this section. For a more comprehensive description of the historical episodes of this topic, refer to Oliveira (1997).

Historical facts will be narrated in four periods: Colonial period (from 1500 to 1807 ); Imperial period (from 1808 to 1889); First Republican period (from 1889 to 1959) and Second Republican period (after 1962).

\section{SEED WORK IN THE COLONIAL PERIOD (1500 TO 1807)}

This period was characterized by the introduction of new species of seed and plant material from abroad, such as several fruit species, sugarcane from the Madeira Islands, oriental spices (pepper, cinnamon, ginger, clover and nutmeg), cotton from Persia and coffee. This last crop was introduced in Brazil by Francisco de Melo Palheta in 1727, from the French Guyana into the city of Belem, state of Para. From this state, it was taken to Maranhão and then to Rio de Janeiro, in 1760. After this period, coffee had spread throughout Southeastern and Southern states. In 1860, coffee became our most important export crop. The period from this year to 1930 was characterized as the "Coffee Cycle," which resulted in significant economical growth in Brazil.

The establishment of Brazilian agriculture occurred after 1530. In that year, an expedition of five ships and over 400 people, commanded by Martim Afonso de Souza, "brought tools, seeds, plant material and domesticated animals to be used in the establishment of the first Brazilian communities." It is reported that Martim Afonso handed European fruit seeds to Diogo Alvares Correia, nicknamed "Caramuru," to conduct agricultural experiences in the state of Bahia. During this period, the Jesuits played an important role in the production, diffusion and commercialization of several plant species in different Brazilian regions.

\section{THE IMPERIAL PERIOD (1808 TO 1889)}

A great input to agricultural research occurred in Brazil with the arrival of the Portuguese Court. In this period, the primordial stages of agricultural research in Brazil were established, with the institution of the Botanical Gardens of Rio de Janeiro in 1808, the Imperial Institute Baiano of Agriculture (IIBA) and the Imperial Institute Fluminense of Agriculture (IIFA) in 1859, by Pedro II. The first agricultural journal in Brazil was edited by IIFA in 1869: the "Revista Agrícola do IIFA."

The year of 1887 was characterized by important achievements: the Imperial Agronomic Station of Campinas (today - Agronomic Institute of Campinas) and the National Society of Agriculture were established. These recently founded institutions were responsible for the multiplication and distribution of seeds, for the adoption of new cultivation methods and techniques, introduction of new equipment, new varieties and for the regulation of seed use and analysis.

The introduction of several important species occurred in this period, such as wheat, barley, jute, eucalyptus and alfalfa. 


\section{FIRST REPUBLICAN PERIOD (1889 TO 1959)}

Important facts were registered in this period. The foundation of several schools of agriculture: School of Agriculture and Veterinary Medicine of Rio de Janeiro in 1898; School of Agriculture of Piracicaba (today ESALQ) in 1901; University of Viçosa in 1917.

This period was characterized by the recognition of the importance of seeds by the government, with the institution in 1910 , by the Ministry of Agriculture, of the Service of Distribution of Plants and Seeds, which served as a base for the establishment of the Seeds Service (Serviço de Sementeiras) in 1920. This service had specific attributions related to seed multiplication, distribution, production control and analysis. In 1931, the Laboratory of Seed Analysis and Inspection was founded in Rio de Janeiro and, during the 1930's, it organized the seed production system and the first legislation related to this sector.

In the 1940's, seed research was being carried out in several agricultural stations: in Coronel Pacheco and Sete Lagoas, MG, with corn wheat and other cereals; Itapecirica and Deodoro, RJ, with some fruit seeds; Pelotas, RS, with vegetable crop seeds.

Another important achievement took place in 1954: the release of the first version of the Brazilian Rules for Testing Seeds, which were updated in 1967, 1976 and 1992.

\section{SECOND REPUBLICAN PERIOD (AFTER 1960)}

Substantial development occurred in this period, relating to the structuring of the Brazilian seed industry (private and governmental sectors), to the development of more appropriate legislation, organization of seed seminars and congresses and specific seed programs. Great achievements were observed in the research sector.

In 1963, during the IV Pan-American Seed Seminar, which was held in Rio, the institution of the Seed State Commissions was recommended, with the purpose of establishing seed production guidelines and seed standards for commercialization. The first State Commissions were created in the Southern region, initially for wheat seeds, and later on they were adopted by several other Brazilian states.

From 1964 to 1966, a cooperation program involving the Brazilian government, USAID and
Mississippi State University was initiated. Seed laboratory equipment was acquired to several laboratories, training courses were offered and consultation was performed.

In this decade, private seed companies were structured, such as Agroceres, Cargill, Anderson Clayton and Refinações de Milho Brasil. At the same time, seed research received good governmental support. A landmark in seed research was the organization of the I Brazilian Seed Seminar in Viçosa, MG, in 1967. In this event, a national policy for seed production was established that limited governmental actions to commerce surveillance, seed certification and foundation seed production.

The most important fact relating to the development of seed research in Brazil was the establishment by the Brazilian government of National Seed Plan (PLANASEM) in 1968. PLANASEM was implemented in 1973 by the subprogram called Governmental Support to the National Seed Plan (AGIPLAN), which involved seed production and research activities. A cooperation program involving AGIPLAN, USAID and Mississippi State University was established with the objective of training Brazilian seed specialists in American universities: more than 50 Brazilians completed their Master of Science and Ph.D. degrees in seed technology during the 1970's. In addition, AGIPLAN interacted intensively with ESALQ and UFPEL. From 1973 to 1975, these two institutions offered several intensive training programs to 828 persons involved in seed production, certification, research and analysis.

In 1978, National Seed Commission (CONASEM) was created. This organization was composed of representative members of the Ministry of Agriculture, official research and extension institutions, private seed production organizations and cooperatives, the agricultural education sector and by industry and commerce federations. CONASEM had the objectives of setting up the national seed policies regarding legislation, research priorities definition and integration between private and official sectors.

In this decade, the Brazilian system of agricultural research was re-structured, with the institution, in 1973, of Brazilian Corporation for Agricultural Research (EMBRAPA), a federal organization whose major objectives were to coordinate and to conduct agricultural research nation wide. 
AGIPLAN generated several publications about seed production and research and edited the Journal "Semente," which was short lived, with only two issues published. In 1976, after the three-year period of AGIPLAN's existence, all its technical and administrative personnel were absorbed by the several units of EMBRAPA.

Brazilian Association of Seed Technologists (ABRATES), a private organization, was created in Recife, PE, in 1970. Today more than 700 seed specialists are associated with this organization. ABRATES publishes a scientific journal, the Brazilian Seed Journal (Revista Brasileira de Sementes) and a newsletter, Informativo ABRATES. The Brazilian Seed Seminars that occurred in the late 1960's and early 1970's were expanded by ABRATES into the Brazilian Seed Congress that takes place every other year. Four seminars and ten congresses occurred since 1967 (TABLE 1), with over 2,251 papers presented. Note the evolution in the number of research papers presented following the institution of the Brazilian Seed Congresses: in 1979, during the I Congress, 119 papers were presented; in 1997, during the X Congress, this number was expanded to 454 , meaning almost a fourfold increase in the number of presented papers.

Today, the Brazilian seed industry is well established and is basically composed by private and governmental research institutions, certification agencies, associations of seed producers and certain sectors of the Ministry of Agriculture. The combination of efforts from all these organizations results in the production of high quality seeds that meet the most rigid international standards of quality.

\section{BRAZILIAN PUBLICATIONS IN SEED TECHNOLOGY}

Detailed surveys on the bibliography of Brazilian seed research were mentioned in the introduction. However, Oliveira (1997) presented a review on the evolution of the scientific production of seed technology in Brazil, beginning in the Imperial period (1808) until 1996.

Specific publications on seed technology were not available up to the end of the 19th century. According to Oliveira (1997), the first publication identified in this area dated from 1911 and was entitled "Plants and seeds: practical information about corn whose scientific name is Zea mays" (Plantas e sementes: informações práticas sobre a cultura do milho cujo nome na sciencia é Zea mays), with authorship from the Ministry of Agriculture, Industry and Commerce.

Quantitative evolution for the period from 1900 to 1996 , relating to the production of seed specific publications, is illustrated in TABLE 2 (Oliveira, 1997). Despite constant governmental concern about seed issues, the number of seed related publications issued up to 1969 is discreet, despite the sharp increase in productivity observed in the decade of 1960. Most of the publications edited in this period dealt with specific procedures for the production and commercialization of the most important crops for that time (corn, sugar cane, potato, cotton, coffee, citrus and some vegetable crops) and with seed regulation and legislation, analytical procedures, and very few of them were specifically related to seed technology research.

After 1970, the increase in scientific productivity was evident, after the institution of AGIPLAN, EMBRAPA and ABRATES and with the organization of graduate level courses at several universities. Nine reference publications were edited after this date, mainly with the sponsorship of AGIPLAN and EMBRAPA. During the short period of existence of AGIPLAN, 25 publications were developed. They covered several seed specific subjects, such as seed production, processing, seed treatment and analysis.

With regards to periodicals, the seed technology area presently relies on four regularly edited titles: Brazilian Seed Journal (Revista Brasileira de Sementes - RBS), Newsletter of ABRATES (Informativo ABRATES), Seed News and Seeds Directory from ABRASEM (Anuário ABRASEM). Brazilian Seed Journal is the scientific journal of the area. It was created in 1979, and has published 624 papers in 46 issues, up to 1997. The Newsletter from ABRATES complements the RBS, presenting news, seed related information and scientific notes. Seed News, established in 1996, is a seed magazine with an international vocation, specially in Latin America. Twenty-two thousand issues are printed monthly, disseminating seed related news and information. Anuário ABRASEM is the directory of the Brazilian Association of Seed Producers (ABRASEM). It contains statistical data relating to seed production in Brazil and its articles provide a perspective view for the seed producers.

Other scientific journals that are used for the publication of seed technology papers in Brazil are: PAB-Pesquisa Agropecuária Brasileira, Scientia Agrícola, Científica, Bragantia, Revista de 
Agricultura, Ceres, Revista Brasileira de Fitopatologia, Revista Brasileira de Armazenamento, Arquivo Biológico e Tecnológico e Acta Botânica Brasileira (Oliveira, 1997).

\section{SEED EVENTS IN BRAZIL}

The first seed related event registered in Brazil was the $1^{\text {a }}$ Semana de Sementes ( $1^{\text {st }}$ Seed Week), organized by the Ministry of Agriculture in Sete Lagoas, MG, from July 7 to 15,1935 . The event was composed of an exhibition of seed and living plant parts, agricultural products and sub-products, hands-on training, talks and contests with prizes.

A total of 44 seed related events were registered in Brazil by Oliveira (1997). They involved congresses, seminars, symposia, weeks and workshops. The most important ones were the four seminars and ten congresses (TABLE 1). Other events involved the Brazilian Symposia and Workshops (national and international) in Seed Pathology (7), Seminars and Symposia (national and international) in Forest Seeds (5), National Symposia in Forage Seeds (2) and several other events involving seed production, quality control and marketing. For a detailed review about the subject, please refer to Oliveira (1997).

\section{EVOLUTION OF THE BRAZILIAN SEED CONGRESSES}

The richest source of information on the evolution of seed technology research in Brazil in the last 19 years lies in the collection of 2251 published abstracts of papers presented at the ten Brazilian Seed Congresses (CBS). In the first Congress, 119 papers were presented and in the last, 454 , a significant evolution with regards to the number of papers (TABLE 1).

A quantitative analysis of the number of abstracts presented in all CBS's, according to the type of seed crop, can be performed with the data in TABLE 3. Studies relating to the seed of grain crops were the most widely researched subject, with an average of $48.3 \%$ of all abstracts. From these grain crops, soybean was the crop with the largest number of presented papers, with 370 (a mean of $16.4 \%$ of the papers). This is a result of the importance of this crop to the nation: in 1998, Brazil, the second soybean producer in the world, harvested close to 32 million tons, equivalent to US\$ 5.8 billion. Following soybean, were corn $(7.5 \%$ of the papers), rice $(6.2 \%)$, beans $(6.0 \%)$, cotton $(3.8 \%)$, wheat $(2.3 \%)$ and sunflower $(1.9 \%)$.

TABLE 1 - List of the Brazilian Seed Seminars and Congresses, from 1967 to 1997.

\begin{tabular}{lccc}
\hline EVENT & YEAR & LOCATION & No. OF PAPERS \\
\hline Braz. Seed Seminars & & & 21 \\
I SBS ${ }^{1}$ & 1967 & Viçosa, MG & 49 \\
II SBS & 1968 & Pelotas, RS & 47 \\
III SBS & 1970 & Recife, PE & 31 \\
IV SBS & 1973 & Fortaleza, CE & 148 \\
Total & - & - & 119 \\
\hline Braz. Seed Congresses & & & 120 \\
I CBS & 1979 & Curitiba, PR & 154 \\
I1 CBS & 1981 & Recife, PE & 214 \\
III CBS & 1983 & Campinas, SP & 191 \\
IV CBS & 1985 & Brasília, DF & 142 \\
V CBS & 1987 & Gramado, RS & 203 \\
VI CBS & 1989 & Brasília, DF & 286 \\
VII CBS & 1991 & Campo Grande, MS & 368 \\
VIII CBS & 1993 & Foz do Iguaçu, PR & 454 \\
IX CBS & 1995 & Florianópolis, SC & 2,251 \\
X CBS & 1997 & Foz do Iguaçu, PR & \\
Total & - & - & \\
\hline
\end{tabular}

Source: Annals of the Brazilian Seed Seminars and Congresses.

${ }^{1}$ SBS stands for "Seminário Brasileiro de Sementes" (Brazilian Seed Seminar).

${ }^{2}$ CBS stands for "Congresso Brasileiro de Sementes (Brazilian Seed Congress). 
Comparing these numbers with the ones presented by Oliveira (1997) for the four Brazilian Seed Seminars, which occurred from 1967 to 1973 , we can notice two big shifts. Soybean at that time was not as important as it is today and the percentage of papers presented in all seminars was only $7.2 \%$. On the other hand, wheat was receiving great support from the government at that time to increase its production. Because of this fact, wheat was an important crop during these years and, as a consequence, $16.0 \%$ of the papers presented in the seminars were about this crop. During the $10^{\text {th }} \mathrm{CBS}$, only seven abstracts were presented for wheat (a mean of only $1.5 \%$ of all abstracts).
Another interesting fact can be observed from TABLE 3 with sunflower. The number of abstracts presented for this crop in 1983 peaked to 14. This resulted from more funding given by EMBRAPA to the crop, for studying sunflower as a possible alternative for producing bio-diesel.

It is worthy to observe the increasing number of abstracts presented for forest seeds in the last four CBS's. It is notorious that the group of seed researchers working with this type of crop is getting more organized and is increasing in number, perhaps as a consequence of the increasing level of importance of the ecological concerns relating to the preservation of several of these forest and native seeds.

TABLE 2 - Number of publications related to seeds, from 1900 to 1996.

\begin{tabular}{lcrrrrrrrrrr}
\hline Type of Publication & $1900 / 19$ & $1920 / 9$ & $1930 / 9$ & $1940 / 9$ & $1950 / 9$ & $1960 / 9$ & $1970 / 9$ & $1980 / 9$ & $1990 / 6$ & $\mathrm{n} / \mathrm{d}^{1}$ & Total \\
\hline Periodical & 4 & 11 & 35 & 34 & 75 & 455 & 386 & 333 & 307 & 14 & 1654 \\
Seed Events & & & & & & 70 & 210 & 984 & 1362 & & 2626 \\
Other Events & & 9 & 13 & & & 20 & 257 & 88 & 35 & 4 & 426 \\
Folders/Pamphlets & 3 & 6 & 12 & & 3 & 55 & 196 & 99 & 28 & 87 & 489 \\
Monographs & 1 & 5 & 3 & 1 & & 25 & 130 & 68 & 39 & 17 & 289 \\
Movies & & & 2 & 5 & & & & & 1 & & 8 \\
\hline TOTAL & 8 & 31 & 65 & 40 & 78 & 625 & 1179 & 1572 & 1172 & 122 & 5492 \\
\hline
\end{tabular}

${ }^{1} \mathrm{n} / \mathrm{d}$ : not dated.

Source: Oliveira (1997).

TABLE 3 - Number of abstracts presented in the ten Brazilian Seed Congresses, according to crop type.

\begin{tabular}{lrrrrrrrrrrrr}
\hline CROP & 1st & 2nd & 3rd & 4th & 5th & 6th & 7th & 8th & 9th & 10th & \\
& CBS & CBS & CBS & CBS & CBS & CBS & CBS & CBS & CBS & CBS & Total & $\%$ \\
\hline Grain Crops & 65 & 66 & 86 & 106 & 87 & 81 & 115 & 139 & 144 & 199 & 1088 & 48.3 \\
Soybean & 28 & 16 & 26 & 39 & 26 & 16 & 45 & 51 & 56 & 67 & 370 & $(16.4)$ \\
Corn & 8 & 6 & 4 & 8 & 7 & 14 & 22 & 31 & 27 & 43 & 170 & $(7.5)$ \\
Rice & 8 & 8 & 10 & 14 & 11 & 17 & 9 & 16 & 19 & 28 & 140 & $(6.2)$ \\
Beans & 5 & 13 & 11 & 13 & 18 & 13 & 21 & 11 & 10 & 20 & 135 & $(6.0)$ \\
Cotton & 6 & 8 & 4 & 9 & 5 & 4 & 7 & 12 & 18 & 13 & 86 & $(3.8)$ \\
Wheat & 2 & 3 & 4 & 6 & 10 & 5 & 6 & 5 & 3 & 7 & 51 & $(2.3)$ \\
Sunflower & 2 & 2 & 14 & 7 & 2 & 7 & 0 & 2 & 0 & 6 & 42 & $(1.9)$ \\
Other & 6 & 10 & 13 & 10 & 8 & 5 & 5 & 11 & 11 & 15 & 94 & $(4.2)$ \\
\hline Forest Seed & 11 & 17 & 6 & 33 & 32 & 10 & 37 & 40 & 95 & 81 & 362 & 16.1 \\
\hline Forage Crops & 5 & 9 & 22 & 35 & 17 & 20 & 21 & 19 & 30 & 17 & 195 & 8.7 \\
\hline Vegetable Crops & 11 & 8 & 2 & 15 & 20 & 12 & 19 & 33 & 22 & 12 & 154 & 6.8 \\
\hline Other Species & 27 & 20 & 38 & 25 & 35 & 19 & 11 & 55 & 77 & 145 & 452 & 20.1 \\
\hline TOTAL & 119 & 120 & 154 & 214 & 191 & 142 & 203 & 286 & 368 & 454 & 2251 & 100.0 \\
\hline
\end{tabular}

${ }^{1}$ CBS stands for Congresso Brasileiro de Sementes (Brazilian Seed Congress).

Source: Annals of the ten Brazilian Seed Congresses. 
This tendency is also noticeable in TABLE 4 , which shows that the number of papers relating to the group of forest, fruit, ornamental and medicinal seeds has been increasing in previous CBS's. The number of papers presented in the subject areas of "production, analysis, physiology and morphology" has also been increasing, despite the fact that the equivalent percentage that they represent has been decreasing (TABLE 4).

Among the five types of institutions identified in TABLE 5, the universities were responsible for the production of $53.8 \%$ of all abstracts presented, followed by the EMBRAPA units (with 21.3\%) and by the group composed of research institutions, state research organizations and units of the Ministry of Agriculture (with 19.9\%). It is interesting to note that the number of papers presented by the universities were smaller than the ones presented by the EMBRAPA units in the first two CBS's.

The participation of private companies in seed research has been increasing in previous CBS's (TABLE 5). This fact might be a consequence of the expanding interaction between the private sector and public institutions for the performance of agricultural research. The interrelationship among research institutions can be observed in TABLE 5. In all 2251 abstracts presented in the CBS's, there were 2981 citations of institutions responsible for the research. This means an average of 1.32 institutions interacting per abstract presented.

Among the universities, the data in TABLE 6 identify the Federal University of Pelotas as the most productive unit, with 231 abstracts, followed by ESALQ (209 abstracts), UFV (175), UNESPJaboticabal (170) and by UFLA (153). Among EMBRAPA units, the Soybean Center (CNPSo) was the most productive, with 127 papers, followed by the Foundation Seed Units (SPSB - with 87), Genetic Resources and Biotecnology (CENARGEN - with 81) and Oriental Amazon Center (CPATU - with 38). IAC-Agronomic Institute of Campinas, with 82 abstracts, was the most productive unit among the group of institutions composed of state agronomic institutes and by the Ministry of Agriculture units. IAC was followed by CATI (with 64 abstracts), IAPAR (51) and by IPAGRO (49).

In the study performed by Oliveira (1997), other interesting facts are mentioned about the CBS's, such as the most productive authors and the number of abstracts according to the technical sessions and to the different specialties. She also presents a similar study relating to the four Brazilian Seed Seminars that occurred between 1967 and 1973.

\section{TEACHING SEED TECHNOLOGY IN BRAZIL}

The first specific training courses in seed technology were offered in Brazil in 1959 by Instituto de Pesquisa e Experimentação Agropecuárias do Sul - IPEAS (Institute of Agricultural Research and Experimentation of the South) in conjunction with Centro de Treinamento e Informação do Sul CETREISUL (Training and Information Center of the South). One hundred and sixty one agronomists from the Southern States were trained in wheat inspection for pathological problems (Wetzel, 1968, cited by Oliveira, 1997). From 1962 to 1968, six additional seed technology courses were offered, training 125 seed technicians. From 1973 to 1975 , AGIPLAN, in cooperation with UFPEL and ESALQ in Brazil, and with Mississippi State University in the USA, were responsible for the qualification of several seed specialists in public and private sectors. The seeds planted by these specialists resulted in the improvement of our seed production and training programs.

Undergraduate and graduate level courses in seed technology are well structured in several Brazilian universities due to the implementation of this cooperative work. According to Oliveira (1997), the number of Master of Science and Doctoral theses and dissertations defended in Brazilian universities reached 747 (636 for MS and 111 for DR) up to 1996. The Federal University of Pelotas (UFPEL), with 174 theses and dissertations, is the most productive one, followed by ESALQ from the University of Sao Paulo with 171 and by the Federal University of Viçosa (UFV) with 132. These three universities were ranked in this same order with regards to the number of abstracts presented in all Brazilian Seed Congresses (TABLE 6).

Other universities have good productivity in graduate level courses in seed technology: UNESPJaboticabal, the Federal University of Lavras (UFLA), the Federal University of Paraiba (UFPB), UNESP-Botucatu and UNICAMP-Campinas.

As a curiosity, Oliveira (1997) mentioned that the first thesis, relating to seed research in Brazil, was defended by Lair Resnusat Renno, in 1941, at the Faculdade de Botânica Aplicada à Farmácia (Faculty of Botany Applied to Pharmacy) from the University of Minas Gerais, with the title "Semente: 
TABLE 4 - Number of papers presented at the ten Brazilian Seed Congresses, according to three areas of classification.

\begin{tabular}{|c|c|c|c|c|c|c|c|c|c|c|c|}
\hline AREA $^{1}$ & $\begin{array}{c}1 \mathrm{st} \\
\mathrm{CBS}^{2}\end{array}$ & $\begin{array}{l}\text { 2nd } \\
\text { CBS }\end{array}$ & $\begin{array}{l}\text { 3rd } \\
\text { CBS }\end{array}$ & $\begin{array}{l}\text { 4th } \\
\text { CBS }\end{array}$ & $\begin{array}{l}5 \text { th } \\
\text { CBS }\end{array}$ & $\begin{array}{l}\text { 6th } \\
\text { CBS }\end{array}$ & $\begin{array}{l}\text { 7th } \\
\text { CBS }\end{array}$ & $\begin{array}{l}\text { 8th } \\
\text { CBS }\end{array}$ & $\begin{array}{l}\text { 9th } \\
\text { CBS }\end{array}$ & $\begin{array}{l}\text { 10th } \\
\text { CBS }\end{array}$ & Total \\
\hline Production, Analysis, & 97 & 84 & 119 & 140 & 121 & 99 & 132 & 205 & 218 & 271 & 1,486 \\
\hline Physiology and Morphology & $(81.5 \%)$ & $(70.0 \%)$ & $(77.3 \%)$ & $(65.4 \%)$ & $(63.3 \%)$ & $(69.7 \%)$ & $(65.0 \%)$ & $(71.7 \%)$ & $(59.3 \%)$ & $(59.7 \%)$ & $(66.0 \%)$ \\
\hline Pathology and Seed & 22 & 20 & 32 & 39 & 38 & 33 & 34 & 41 & 34 & 71 & 364 \\
\hline Treatment & $(18.5 \%)$ & $(16.7 \%)$ & $(20.8 \%)$ & $(18.2 \%)$ & $(19.9 \%)$ & $(23.3 \%)$ & $(16.7 \%)$ & $(14.3 \%)$ & $(9.2 \%)$ & $(15.6 \%)$ & $(16.2 \%)$ \\
\hline Forest, Fruit, Ornamental and & 0 & 16 & 3 & 35 & 32 & 10 & 37 & 40 & 116 & 112 & 401 \\
\hline Medicinal Seeds & $(0.0 \%)$ & $(13.3 \%)$ & $(1.9 \%)$ & $(16.4 \%)$ & $(16.8 \%)$ & $(7.0 \%)$ & $(18.3 \%)$ & $(14.0 \%)$ & $(31.5 \%)$ & $(24.7 \%)$ & $(17.8 \%)$ \\
\hline TOTAL & 119 & 120 & 154 & 214 & 191 & 142 & 203 & 286 & 368 & 454 & 2,251 \\
\hline
\end{tabular}

${ }^{1}$ Based on the grouping of the Technical Sections of the Congresses; ${ }^{2} \mathrm{CBS}$ stands for Congresso Brasileiro de Sementes (Brazilian Seed Congress); Source: adapted from Oliveira (1997). 
TABLE 5 - Distribution of the institutions according to the number of papers presented in the ten Brazilian Seed Congresses, from 1979 to 1997.

\begin{tabular}{|c|c|c|c|c|c|c|c|c|c|c|c|}
\hline ISTITUTION & $1 \mathrm{st}$ & 2 nd & $3 \mathrm{rd}$ & 4th & 5 th & 6th & 7th & 8th & 9th & $10^{\text {th }}$ & TOTAL \\
\hline & $\mathrm{CBS}^{1}$ & CBS & CBS & CBS & CBS & CBS & CBS & CBS & CBS & CBS & \\
\hline Universities & 48 & 58 & 64 & 131 & 135 & 118 & 150 & 228 & 297 & 375 & $\begin{array}{c}1604 \\
(53.8 \%)\end{array}$ \\
\hline $\begin{array}{l}\text { Units of } \\
\text { EMBRAPA }\end{array}$ & 63 & 60 & 58 & 64 & 47 & 26 & 51 & 73 & 64 & 128 & $\begin{array}{c}634 \\
(21.3 \%)\end{array}$ \\
\hline $\begin{array}{l}\text { Research Institutes, State Research } \\
\text { Organizations, Min. of Agriculture }\end{array}$ & 33 & 41 & 60 & 83 & 68 & 24 & 52 & 47 & 95 & 65 & $\begin{array}{c}568 \\
(19.0 \%)\end{array}$ \\
\hline Private Companies & 1 & 2 & 2 & 8 & 5 & 6 & 4 & 5 & 25 & 38 & $\begin{array}{c}96 \\
(3.2 \%)\end{array}$ \\
\hline International Institutions & 10 & 2 & 5 & 15 & 5 & 11 & 6 & 10 & 5 & 10 & $\begin{array}{c}79 \\
(2.7 \%) \\
\end{array}$ \\
\hline TOTAL & 155 & 163 & 189 & 301 & 260 & 185 & 263 & 363 & 486 & 616 & 2981 \\
\hline
\end{tabular}

${ }^{1}$ CBS stands for Congresso Brasileiro de Sementes (Brazilian Seed Congress).

Source: Annals of the Brazilian Seed Congresses.

TABLE 6 - Number of papers presented in ten Brazilian Seed Congresses, from 1979 to 1997, by several universities, EMBRAPA units and other institutions.

\begin{tabular}{lclclc}
\hline UNIVERSITY & $\begin{array}{c}\text { No. OF } \\
\text { ABSTRACTS }\end{array}$ & $\begin{array}{c}\text { UNIT OF } \\
\text { EMBRAPA }\end{array}$ & $\begin{array}{c}\text { No. OF } \\
\text { ABSTRACTS }\end{array}$ & INSTITUTION $^{1}$ & $\begin{array}{c}\text { No. OF } \\
\text { ABSTRACTS }\end{array}$ \\
\hline UFPEL-Pelotas & 231 & CNPSo & 124 & IAC & 82 \\
ESALQ-Piracicaba & 209 & SPSB & 87 & CATI & 64 \\
UFV-Viçosa & 175 & CENARGEN & 81 & IAPAR & 51 \\
UNESP-Jaboticabal & 170 & CPATU & 38 & IPAGRO & 49 \\
UFLA-Lavras & 153 & CPAC & 35 & EPAMIG & 44 \\
UFPB-C. Grande & 71 & CNPH & 35 & Inst. Botânica-SP & 27 \\
UFRRJ-Seropédica & 69 & CPATSA & 32 & Min. da Agricultura & 27 \\
UNESP-Botucatu & 54 & CNPMS & 31 & Inst. Florestal-SP & 26 \\
UNICAMP-Campinas & 44 & CNPA & 29 & PESAGRO-Rio & 22 \\
UNESP-I. Solteira & 34 & CPACT & 24 & Jardim Botânico-RJ & 14 \\
Other & 394 & Other & 118 & Other & 162 \\
\hline TOTAL & 1604 & - & 634 & - & 568 \\
\hline
\end{tabular}

${ }^{1}$ State institutes of agricultural research and extension and units of the Ministry of Agriculture.

Source: Annals of the Brazilian Seed Congresses.

disseminação e germinação" (Seeds: dissemination and germination). The first thesis submitted for a Doctoral degree was completed in 1950 by Nelson Kobal, at the University of Sao PauloESALQ, with the title "Estudos sobre a genética da coloração no endosperma das sementes de milho" (Studies on the genetics of endosperm color of corn seeds).

\section{TENDENCIES OF SEED RESEARCH IN BRAZIL}

To indicate possible tendencies of seed research in Brazil is simple. Difficulties will occur a few years from now, when we compare what really happened with our predictions. However, despite this level of uncertainty, some tendencies can be pointed out, based on surveys and changes that have 
been occurring in seed research lines over the past years.

It is our opinion that some lines of research in seed science will not change much in the next five years, such as drying and seed processing. For some species, such as soybean, because of their expansion into tropical environments, some efforts will be directed towards the development of specific seed production techniques for these conditions. For example: field production techniques - determination of best sowing dates for seed production, specific harvesting procedures; specific storage procedures for the tropics - new packaging materials, alternative methods for storage; breeding for improved seed quality - this research line is basic for the successful expansion of these crops in the tropics.

In the area of molecular biology, there has been an increasing tendency to conduct specific research to explain certain physiological changes that occur in some seeds, during the processes of maturation, deterioration, consequences of exposure of seeds and plants to stressful conditions, such as drought, heat, cold and to infection by certain pathogens. The expression of some macromolecules, such as DNA, RNA, specific proteins (lea, hsp, biotinylated proteins), enzymes and isoenzymes, associated with the above mentioned processes is a reality and will tend to increase over the next five years.

Use of computers for image analysis is another expanding field in seed science. Use of these techniques for variety identification, determination of seed viability and the expression of certain types of damage to the seeds will also tend to expand.

Vigor testing will also expand. The seed industry demands the development and perfection of analysis techniques that can be adopted for the determination of vigor potential of the produced seeds. Correlating these vigor results with field performance will be in the mind of several seed researchers.

In her Doctoral dissertation, Oliveira (1997) presented the results of a survey she applied to several experienced and productive researchers and professors involved in seed science. According to the opinion of these seed experts, in the next five years, the following changes are expected according to the line of research: seed drying and machinery little or no change from what is being done today; seed storage, analysis, production techniques, physiology, post-harvest technology, legislation and human resources qualification - a medium development level is expected; seed pathology and quality control are the areas expected to have a high level of development. Some of these seed specialists included biotecnology, marketing and the use of computers as areas with good development potential for future research. Studies with seeds from native species are also expected to occur.

If it is important to keep our seed research alive, it is imperative to bare in mind the importance of constant replacement of retiring seed researchers and professors with other seed specialists. An unfortunate example occurred recently with the seed research program developed at the Seed Technology Laboratory of Mississippi State University. Replacement did not occur and their seed research program does not exist anymore.

\section{REFERENCES}

CONGRESSO BRASILEIRO DE SEMENTES, 1. 1979, Curitiba-PR. Resumos dos trabalhos técnicos. Curitiba: ABRATES, 1979. 136p.

CONGRESSO BRASILEIRO DE SEMENTES, 2. 1981, Recife-PE. Resumos dos trabalhos técnicos. Brasília: ABRATES, 1981. 145p.

CONGRESSO BRASILEIRO DE SEMENTES, 3. 1983, Campinas-SP. Resumos dos trabalhos técnicos. Brasília: ABRATES, 1983. 189p.

CONGRESSO BRASILEIRO DE SEMENTES, 4. 1985, Brasília-DF. Resumos dos trabalhos técnicos. Brasília: ABRATES, 1985. 209p.

CONGRESSO BRASILEIRO DE SEMENTES, 5. 1987, Gramado-RS. Resumos dos trabalhos técnicos. Brasília: ABRATES, 1987. 245p.

CONGRESSO BRASILEIRO DE SEMENTES, 6. 1989, Brasília-DF. Resumos dos trabalhos técnicos. Brasília: ABRATES, 1989. 128p.

CONGRESSO BRASILEIRO DE SEMENTES, 7. 1991, Campo Grande-MS. (Resumos) In. Informativo ABRATES, v.1, n.4, set.1991. (Número especial)

CONGRESSO BRASILEIRO DE SEMENTES, 8. 1993 , Foz do Iguaçu-PR. (Resumos) In. Informativo ABRATES, v.3, n.3, junho 1993. (Número especial)

CONGRESSO BRASILEIRO DE SEMENTES, 9. 1995, Florianópolis-SC. (Resumos) In. Informativo ABRATES, v.5, n.2, p.1-222, agosto 1995. (Número especial) 
CONGRESSO BRASILEIRO DE SEMENTES, 10. 1997, Foz do Iguaçu-PR. (Resumos) In. Informativo ABRATES, v.7, n.1/2,julho/ago. 1997. (Número especial)

EMBRAPA. Bibliografia Brasileira de Sementes (Brazilian Seed Bibliography). Brasília: EMBRAPA-DID, 1980-83. 5v

EMBRAPA-CNPH (Brasília, DF). Bibliografia brasileira de sementes de hortaliças (Brazilian bibliography on vegetable crops seeds). Brasília, 1995. 274p. (EMBRAPA-CNPH. Bibliografia, 5).

MENEZES, J.E.; CARVALHO, E.R.; BETTIOL, E.M. Bibliografia brasileira de semente: análise quantitativa. Brasília: EMBRAPA-DID, 1981. 43p.

OLIVEIRA, M.J. A pesquisa em sementes no Brasil: produção científica e tendências de desenvolvimento. Brasília, 1997. 208p. Tese (Doutorado) - Faculdade de Estudos Sociais Aplicados, Universidade de Brasília.
OLIVEIRA, M.J. Contribuição da Revista Brasileira de Sementes ao desenvolvimento pa pesquisa na área sementeira: um estudo de produtividade. (Contribution of the Brazilian Seed Journal to the seed area: a study of productivity). Cie. Informação, Brasília, v.23, n.3, p.353-358, set./ dez. 1994

POPINIGIS, F. Nota do Editor. Revista Brasileira de Sementes, v.5, n.3, p.9-10, 1983

WETZEL, C.T. Lista bibliográfica de sementes (Bibliographic list of seeds). S.I., Ministério da Agricultura, 1972. 85p.

WETZEL, M.M.V.S.; BETTIOL, E.M.; FAIAD,M.G.R. Bibliografia brasileira de patologia de sementes. Brasília: EMBRAPA-DID, 1981. 256p.

Recebido para publicação em 10/07/98 Aceito para publicação em 03/08/98 